ARTICOLE

\title{
SCRISOARE DE GARANȚIE V. FIDEIUSIUNE. \\ CUM LE DISTINGEM?
}

DOI: 10.24193/SUBBiur.66(2021).2.3

\section{Adrian TAMBA*}

Rezumat: Lucrarea noastră debutează cu niște cuvinte introductive și un plan de lucru. Ea continuă cu o scurtă prezentare a așa-numitei scrisori de garanție. Al treilea paragraf se concentrează, succint, asupra fideiusiunii. Porțiunea finală a studiului de față evidențiază că, în privința distincției dintre scrisoarea de garanție și fideiusiune, diavolul se află în redactare.

Cuvinte cheie: scrisoare de garanție, fideiusiune, distincție.

* Asist. dr. Adrian TAMBA, Facultatea de Drept, Universitatea Babeș-Bolyai, Cluj-Napoca, adrian.tamba@law.ubbcluj.ro, https://orcid.org/0000-0001-8328-3517.

\section{2}




\title{
LETTER OF CREDIT V. SURETYSHIP. HOW DO WE DISTINGUISH THEM?
}

\begin{abstract}
Our paper starts with a few preliminary or introductory words and a work plan. It continues with a brief presentation of the so-called „letter of credit”. The third paragraph briefly focuses on suretyship. The final portion of this paper points out that, on the distinction between the letter of credit and suretyship, the devil is in the drafting.
\end{abstract}

Key words: letter of credit, suretyship, distinguishing.

\section{Cuprins}

I. $\quad$ Vocabule introductive. Plan de lucru................................................ 94

II. Garanția autonomă sau scrisoarea de garanție - o schiță. ............................. 96

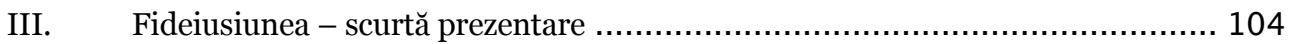

IV. Scrisoarea de garanție v. fideiusiune. Cum le diferențiem? ....................... 109 


\section{Vocabule introductive. Plan de lucru}

În teorie, garanția autonomă (i.e., scrisoarea de garanție ${ }^{1}$ ) și fideiusiunea sunt două mecanisme cât se poate de diferite ${ }^{2}$. La nivel de principiu, specificitatea garanției autonome în raport de fideiusiune nu mai este discutată $\breve{3}^{3}$. Intr-adevăr, suntem anunțați că fideiusiunea se opune unei instituții vecine: garanția autonomă4 .

${ }^{1}$ Garanția autonomă mai este denumită și garanție la prima cerere, garanție independentă sau scrisoare de garanție. A se vedea, Y. PICOD, Droit des sûretés, $3^{\mathrm{e}}$ édition mise á jour, Presses Universitaires de France, Paris, 2008, p. 234, nr. 135. Așadar, expresiile „garanție autonomă”, „garanție la prima cerere”, „garanție independentă” și „scrisoare de garanție” sunt sinonime. A se vedea și H. et L. Mazeaud, J. Mazeaud, Fr. Chabas, Leçons de droit civil, tome III, premier volume, Sûretés. Publicité foncière, $7^{\mathrm{e}}$ édition par Y. PICOD, Montchrestien, Paris, 1999, p. 109, nr. 53-2 (,[1] garantie à première demande - aussi appelée garantie autonome, garantie indépendante, lettre de garantie ...”).

Alți autori sunt tentați să creadă că garanția la prima cerere este cea mai întâlnită varietate de garanție autonomă. A se vedea, Ch. Albiges, M.-P. Dumont, Droit des sûretés, 7e édition, Dalloz, Paris, 2019, p. 219, nr. 250. Astfel, dacă îi credem pe Christophe ALBIGES și pe MariePierre DumONT, noțiunile cunoscute drept „garanție la prima cerere” și „garanție autonomă” nu sunt totuna.

Dominique LEGEAIS pretinde că garanțiile independente sunt desemnate sub numele de garanție autonomă ori garanție la prima cerere. A se vedea, D. LEGEAIs, Droit des sûretés et garanties du crédit, 13e édition, LGDJ, Paris, 2019, p. 282, nr. 335 („,[e]lles (i.e., les garanties indépendantes - nota ns., A.T.) sont aussi désignées sous le nom de garantie autonome ou de garantie à première demande”). LEGEAIs ne dă de înțeles că „garanții independente”, „garanție autonomă” și „garanție la prima cerere” sunt „creaturi” care trăiesc în sinonimie.

${ }^{2}$ Ch. Albiges, M.-P. Dumont, Droit des sûretés, 7e édition, Dalloz, Paris, 2019, p. 227, nr. 272.

$3 \mathrm{Ph}$. Simler, Cautionnement. Garanties autonomes. Garanties indemnitaires, 5 édition, LexisNexis, Paris, 2015, p. 941, nr. 925.

4 P. TAFforeau, Droit des sûretés. Sûretés personnelles et réelles, 1re édition, Bruylant, Bruxelles, 2020, p. 65, nr. 86.

\section{4}


Spuse fiind acestea, nu mică ne este mirarea când aflăm că, relativ la distincția dintre garanția autonomă și fideiusiune, contenciosul este clasic și abundent ${ }^{5}$.

În rândurile care urmează, vom schița garanția autonomă (infra., nr. 2). Mai departe, fideiusiunea va fi scoasă în lumină, cât se poate de succint (infra., nr. 3). Bineînțeles, ne vom strădui să arătăm cum pot fi deosebite cele două entităţi (i.e., scrisoarea de garanție și fideiusiunea) (infra., nr. 4).

„[L]'écrivain est maître de ce qu'il écrit", credea Alfred Fouillée ${ }^{6}$. Fïnd stăpâni ai ceea ce scriem, ne îngăduim să elaborăm acest scurt studiu astfel încât să fie văduvit de o secțiune închinată concluziilor. În alte cuvinte, ne permitem să abandonăm, în cercetarea de față, ceea ce am putea numi obişnuita cale ortodoxă.

Înainte să avansăm, nu strică să ne aducem aminte că, în România ${ }^{7}$ și în Franța ${ }^{8}$, fideiusiunea și scrisoarea de garanție sunt privite drept garanții personale ${ }^{9}$ (art. 2279 C.civ. român şi art. 2287-1 C.civ.fr.).

5 A.-S. BARthez, D. HoutciefF, Traité de droit civil (sous la direction de J. Ghestin), Les sûretés personnelles, LGDJ, Paris, 2010, p. 883, nr. 1235.

${ }^{6}$ A. Foulllee, La science sociale contemporaine, Librairie Hachette et Cie, Paris, 1880, p. 262.

${ }^{7}$ R. RizoIU, Curs de garanții civile, Hamangiu, București, 2020, p. 158, nr. 68 („[f]ideiusiunea reprezintă forma tradițională de garanție personală”). P. VASILESCU, Drept civil. Obligațiii, ediția a 2-a revizuită, Hamangiu, București, 2017, p. 126 (,[î]n Codul civil, sunt considerate garanții personale: fideiusiunea, scrisoarea de garanție ...”).

${ }^{8}$ M. Mignot, Droit des sûretés et de la publicité foncière, 3e édition, LGDJ, Paris, 2017, p. 31, $\mathrm{nr} .18$ („[l]e cautionnement est la garantie personnelle type du droit français”; „les autres sûretés personnelles que sont la garantie autonome, la lettre d'intention ..."; s.n., A.T.). ${ }^{9} \mathrm{Ph}$. Simler, Ph. Delebecque, Droit civil. Les sûretés. La publicité foncière, $7^{\mathrm{e}}$ édition, Dalloz, Paris, 2016, p. 31, nr. 38 („[1] e cautionnement reste ... la sûreté personnelle par excellence ...”; „deux autres sûretés personnelles .... LES garanties autonomes ... et la lettre d'intention ...”; s.n., A.T.).

\section{5}




\section{Garanția autonomă sau scrisoarea de garanție - o schiță.}

Băncile americane au fost primele care au emis garanţii independente ${ }^{10}$ și au făcut-o în forma zisă „standby letters of credit” (i.e., „lettres de crédit standby”) ${ }^{11}$. O „standby ${ }^{12}$ letter of credit” se manifestă ca o plasă de siguranță în ipoteza nesocotirii obligațiilor de tot felul, atât monetare cât şi non-monetare ${ }^{13}$. Iată un exemplu: un constructor (i.e., builderapplicant) face aşa încât banca sa (i.e., issuer) să-i scrie beneficiarului (i.e., owner-beneficiary) o „standby letter of credit ${ }^{14 ”}$. Prin scrisoarea standby, banca (i.e., issuer) se angajează să-i plătească o sumă de bani beneficiarului, în măsura în care sunt prezentate două documente: 1) o cerere scrisă prin care se solicită plata sumei indicate în scrisoare, plus 2) o declarație scrisă în care se subliniază că acel constructor (i.e., applicant) nu a executat obligația de a ridica o construcție ${ }^{15}$. Desigur, în afară de obligații non-monetare precum ridicarea unei clădiri, o scrisoare standby poate „asigura” obligații monetare

10 Dominique LEgEAIS ne informează că garanțiile independente, cunoscute și ca garanție autonomă sau garanție la prima cerere, sunt o creație a practicii bancare internaționale. A se vedea, D. LEGEAIS, op.cit., p. 282, nr. 335. LEGEAIS mai afirmă că, în Franța, garanția independentă s-a dezvoltat cu adevărat în anii 1970. A se vedea, D. LEGEAIs, op.cit., p. 282, nr. 336 (,[e]lle (i.e., la garantie indépendante - n.s., A.T.) s'est véritablement développée en France dans les années 1970”).

${ }^{11}$ A se vedea, M. Cabrillac, Ch. Mouly, S. Cabrillac, Ph. PÉTel, Droit des sûretés, 9e édition, LexisNexis, Paris, 2010, p. 345, nr. 468.

12 Standby înseamnă „în aşteptare” (i.e., „en attente”). A se vedea, M. CABrillac, Ch. Mouly, S. CABRILlaC, Ph. PÉTEL, op.cit., p. 345, nr. 468.

13 A se vedea, J. J. White, R. S. Summers, Uniform Commercial Code, sixth edition, West, 2010, p. 1068 (,the standby letter of credit acts as a „back up” against applicant default on obligations of all kinds, both monetary and non-monetary").

14 A se vedea, J. J. White, R. S. Summers, op.cit., p. 1069.

15 Ibidem. 
pure $^{16}$. În ceea ce privește aceste letters of credit, aspectul cel mai interesant este principiul independenței. Respectivul principiu constă în faptul că îndatorirea băncii față de beneficiar este independentă de executarea contractului de bază de către aşa-numitul beneficiar ${ }^{17}$. Într-adevăr, bancaissuer trebuie să plătească la cererea beneficiarului, chiar dacă cel din urmă a nesocotit contractul de bază dintre el şi partenerul său contractual (i.e., the applicant $\left.{ }^{18}\right)$.

Garanția autonomă sau scrisoarea de garanție s-a născut în practica internațională, în domeniul construcțiilor ${ }^{19}$. Cu adevărat, comerțul internațional constituie leagănul garanției autonome ${ }^{20}$. Ea a fost oferită cu ocazia construcției de centrale nucleare în Iran ${ }^{21}$, de conducte în Costa-Rica ${ }^{22}$, de spitale în Paraguay ${ }^{23}$, de drumuri în Rwanda ${ }^{24}$ sau de gazoducte în Argentina ${ }^{25}$. Garanția autonomă, deși ivită în domeniul construcțiilor, a permis garantarea executării contractelor de vânzare încheiate cu Irak, Siria sau Kuweit ${ }^{26}$.

16 Ibid.

${ }^{17}$ A se vedea, J. J. White, R. S. SUMmers, op.cit., p. 1074.

18 Ibid.

${ }^{19}$ A se vedea, M. Mignot, op.cit., p. 219, nr. 558.

20 A se vedea, A.-S. BARThez, D. HoutciefF, Traité de droit civil (sous la direction de J. GHESTIN), op.cit., p. 853, nr. 1220.

${ }^{21}$ A.-S. BARThez, D. HoutciefF, Traité de droit civil (sous la direction de J. GHeSTIN), op.cit., p. 854, nr. 1220.

22 Ibid.

23 Ibid.

${ }^{24}$ Ibid., p. 854-855, nr. 1220.

25 Ibid., p. 855, nr. 1220.

26 A se vedea, A.-S. BArthez, D. Houtcieff, Traité de droit civil (sous la direction de J. GHESTIN), op.cit., p. 855, nr. 1220 [„elle (i.e., la garantie autonome - nota ns., A.T.) a ... permis de garantir l'exécution de contrats de vente passés avec l'Irak, la Syrie ... ou le Koweït”]. 
În zilele noastre, deseori, garanţiile autonome sunt constituite într-un context internațional ${ }^{27}$. Contractul garantat este unul internaţional și garanția presupune unul sau mai multe elemente de extraneitate ${ }^{28}$. Adesea, beneficiarul garanției și garantul sunt situați în două țări diferite ${ }^{29}$. Astfel, ce lege i se va aplica garanției? În principiu, banca-garant își va impune propria lege ${ }^{30}$ (i.e., regulile statului său). În măsura în care părțile nu aleg legea aplicabilă, va trebui să notăm că garanția autonomă este guvernată de legea țării în care garantul îşi are „reședința obișnuită” ${ }^{31}$.

Garanția autonomă s-a strecurat și în sisteme de drept naționale. În România, o regăsim la art. 2321 C.civ. În Franța, prin Ordonanța nr. 2006346 din 20 martie 2006, garanției menționate i s-a găsit un loc în Codul civil francez (art. 2321 C.civ.fr. ${ }^{32}$ ). În țara noastră, garanțiile autonome, așadar inclusiv scrisoarea de garanție, sunt o inovație legislativă a actualului Cod civil $^{33}$, dar nu au fost „fabricate” de acest act normativ; ele erau cunoscute şi practicate de profesioniștii afacerilor, chiar înainte să-și afle drumul în Codul nostru civil ${ }^{34}$. În Franța, scrisoarea de garanție (i.e., garanția autonomă) nu a fost o pură creație a ordonanței din 2006 și a Codului civil francez; ea era

\footnotetext{
${ }^{27}$ M. Mignot, op.cit., p. 228, nr. 583.

28 Ibid.

${ }^{29}$ Ibid.

30 Ibid.

31 Ibid.

32 A se vedea, G. Wiederkehr, X. Henry, A. Tisserand-Martin, G. Venandet, P. Ancel, P. Guiomard, Code civil annoté, 118e édition, Dalloz, Paris, 2018, p. 2699.

33 A se vedea, P. VAsilescu, op.cit., p. 143.

${ }^{34}$ Ibid.
} 
admisă sau acceptată de jurisprudență înainte să fie îmbrățișată de lege (art. 2321 C.civ.fr. ${ }^{35}$ ).

Autonomia scrisorii de garanție exprimă, în mod veritabil, specificitatea sa și constituie inima acestei garanții personale ${ }^{36}$. Autonomia înseamnă că, în afară, e.g., de ipoteza abuzului manifest, garantul trebuie săşi execute angajamentul, fără să-i poată opune beneficiarului apărări cum sunt nulitatea contractului de bază ${ }^{37}$, rezoluțiunea sau rezilierea $\mathrm{sa}^{38}$, neexecutarea lui, chiar dacă nesocotirea ar fi fapta sau culpa creditorului însuși, ar fi generată de fapta autorității ori ar fi urmarea forței majore ${ }^{39}$. Prescripția extinctivă care ar afecta contractul de bază este o apărare inutilizabilă și nu poate împiedica executarea garanției analizate ${ }^{40}$. Mai mult, unii autori sunt de părere că garantul nu poate folosi împotriva beneficiarului nici măcar apărări care constau în moduri de stingere a obligației garantate, precum compensația, confuziunea sau novația ${ }^{41}$. Plata (i.e., executarea) privitoare la contractul de bază n-ar fi de niciun folos, ea neputând stopa executarea garanției ${ }^{42}$. Un doctrinar însă, pare să vadă lucrurile într-un alt fel: el opinează că se impun combătute toate soluțiile potrivit cărora garantul autonom nu este liberat printr-un mod de stingere total şi indiscutabil al

35 A se vedea, M. Mignot, op.cit., p. 219, nr. 558 („[e]lle (i.e., la garantie autonome - nota ns. A.T.) fut admise par la jurisprudence avant de l'être par la loi (art. 2321) ... ”).

${ }^{36}$ A se vedea, Ph. SIMLER, op.cit., p. 932, nr. 915.

${ }^{37}$ A se vedea, Ibid. p. 936, nr. 919; Ph. Simler, Ph. Delebecque, op.cit., p. 289, nr. 293.

38 A se vedea, Ph. Simler, op.cit., p. 936, nr. 919; Ph. Simler, Ph. Delebecque, op.cit., p. 289, nr. 293.

${ }^{39}$ A se vedea, Ph. Simler, op.cit., p. 936, nr. 919.

${ }^{40}$ A se vedea, P. TAFFOREAU, op.cit., p. 232, nr. 465.

${ }^{41}$ A se vedea, Ph. Simler, Ph. Delebecque, op.cit., p. 289, nr. 293.

${ }^{42}$ A se vedea, P. TAFFOREAU, op.cit., p. 232, nr. 465. 
creanței garantate ${ }^{43}$; Mignot explică că garanția nu este, totuși, complet autonomă, n-a fost vreodată total independentă și niciodată nu va putea să fie astfel $^{44}$. Oricum ar fi, nu strică să menționăm că independența scrisorii de garanție are drept consecință faptul că această garanție personală nu se transmite odată cu creanța garantată ${ }^{45}$ [art. 2321 alin (5) C.civ.]; desigur, transmisibilitatea scrisorii de garanție este posibilă prin jocul unei stipulații contrare.

Autonomia sau independența scrisorii de garanție este crucială. O garanție autonomă, ca angajament asumat de o bancă, îi interzice instituției de credit să se prevaleze de excepții pe care societatea debitoare putea să i le opună societății beneficiare a garanției și care țineau de neexecutarea contractului de bază care unea cele două societățiit. Casația franceză a mai decis că, în absența unor stipulații prin care să le fie indicată autonomia, garanțiile acordate de o bancă nu sunt decât niște fideiusiuni ${ }^{47}$.

Deși scrisoarea de garanție este independentă, ea rămâne, totuşi, o garanție. Așadar, este de neconceput ca actul de garanție să fie lipsit de orice referință la contractul de bază sau principal ${ }^{48}$. Bineînțeles că garanțiile nu sunt private de autonomie dacă există simple referințe la contractul de bazăă, dar

\footnotetext{
43 A se vedea, M. Mignot, op.cit., p. 229, nr. 587.

44 Ibid.

45 A se vedea, P. TAFFOREAU, op.cit., p. 232, nr. 466.

46 A se vedea, Com. 20 déc. 1982 (deux arrêts), în G. Wiederkehr, X. Henry, A. TisserandMartin, G. Venandet, P. Ancel, P. Guiomard, op.cit., p. 2699.

47 A se vedea, Com. 15 juin 1999, în G. Wiederkehr, X. Henry, A. Tisserand-Martin, G. Venandet, P. ANCEL, P. Guiomard, op.cit., p. 2700.

48 A se vedea, M. Bourassin, V. Brémond, Droit des sûretés, 7e édition, Sirey, Paris, 2020, p. 396, nr. 567.

49 A se vedea, Com. 30 janv. 2001, în G. Wiederkehr, X. Henry, A. Tisserand-Martin, G. Venandet, P. Ancel, P. Guiomard, op.cit., p. 2700.
} 
pericolul este ca aceste referințe să sugereze că garantul își asumă chiar obligația debitorului, caz în care garanția personală nu mai poate fi una independentă. Pentru a fi cu adevărat în prezența unei garanții autonome (i.e., scrisori de garanție), cuantumul garanției trebuie determinat cu precizie, fără să fie nevoie să se consulte contractul de bază, iar executarea garanției nu trebuie subordonată nesocotirii de către debitor a obligației principale ${ }^{50}$. Suma pe care se angajează s-o plătească garantul poate fi inferioară, egală sau superioară celei datorate în virtutea contractului de bază ${ }^{51}$; cu toate acestea, nu poate fi vorba despre propria datorie a debitorului ${ }^{52}$; garantul autonom nu se angajează să plătească datoria altuia, ci să-şi execute propria sa obligație ${ }^{53}$.

O foarte interesantă problemă este aceasta: ce natură are scrisoarea de garanție? O asemenea garanție personală reprezintă un contract sau un act unilateral? Mai mulți juriști belgieni văd în garanția autonomă un act juridic unilateral ${ }^{54}$. În realitate însă, scrisoarea de garanție se înscrie într-un cadru contractual $^{55}$. Garanția autonomă este un contract ${ }^{56}$. Casația franceză califică scrisoarea de garanție, în mod expres, drept un contract ${ }^{57}$. Autorii români, la rândul lor, stabilesc că scrisoarea de garanție este un contract ${ }^{58}$. Care sunt părțile contractului de garanție independentă? Unii estimează că acest

\footnotetext{
${ }^{50}$ A se vedea, M. Bourassin, V. BRÉMOND, op.cit., p. 396, nr. 568.

${ }^{51}$ A se vedea, Ch. Albiges, M.-P. Dumont, op.cit., p. 225, nr. 269.

52 Ibid.

53 Ibid.

${ }^{54}$ A se vedea, Ph. SIMLER, op.cit., p. 923, nr. 903.

55 Ibid.

56 A se vedea, Ph. Simler, Ph. Delebecque, op.cit., p. 294, nr. 298.

${ }^{57}$ A se vedea, Ph. SIMLER, op.cit., p. 924, nr. 903.

58 P. VASIlESCU, op.cit., p. 145. A se vedea şi R. RIZOIU, op.cit., p. 259, nr. 113.
}

\section{1}


contract de garanție se încheie între ordonator și garant ${ }^{59}$. Alții ne supun atenției faptul că sunt contractanți într-o scrisoare de garanție garantul și beneficiarul ${ }^{60}$. În opinia noastră, parteneri contractuali într-o scrisoare de garanție sunt garantul şi beneficiarul. Ordonatorul este debitorul din contractul de bază, iar beneficiarul este creditor în acest contract ${ }^{61}$. Garanția personală este o convenție ce poate avea loc doar între creditor (în cazul nostru, beneficiar) și garant.

În clipa în care îşi face apariția o scrisoare de garanție, ne putem lovi de o trihotomie de contracte. Ne vom regăsi, deci, în prezența unui contract zis de bază (e.g., vânzare, antrepriză), încheiat între beneficiar și ordonator ${ }^{62}$. Mai există, apoi, un contract de credit închegat între garant (i.e., emitent) și ordonator ${ }^{63}$. Pe această convenție de credit se sprijină majoritatea autorilor atunci când explică regresul pe cale personală al garantului, exercitat împotriva ordonatorului ${ }^{64}$. În sfârşit, se impune zărit însuşi contractul de scrisoare de garanție, realizat între garantul-emitent şi beneficiar ${ }^{65}$. În scrisoarea de garanție, obligația emitentului este, tot timpul, una pecuniară: el se îndatorează să plătească o sumă de bani [art. 2321 alin. (1) C.civ.]. Scrisoarea de garanție garantează o creanță pecuniară sau non-pecuniară din

${ }^{59}$ A se vedea, Y. Picod, op.cit., p. 235, nr. 136.

${ }^{60}$ A se vedea, P. TAFFOREAU, op.cit., p. 226, nr. 446-1.

${ }^{61}$ A se vedea, Ch. Albiges, M.-P. Dumont, op.cit., p. 220, nr. 254 („le donneur d'ordre qui n'est autre que le débiteur”; „le bénéficiaire de la garantie, c'est-à-dire le créancier”). Contractul de bază, desigur, se perfectează între beneficiar și ordonator. A se vedea, P. TAFFOREAU, op.cit., p. 226, nr. 446-1.

62 A se vedea, P. TAFFOREAU, op.cit., p. 225, nr. 446 și p. 226, nr. 446-1.

63 A se vedea, A.-S. BARThez, D. HoutciefF, Traité de droit civil (sous la direction de J. Ghestin), op.cit., p. 994, nr. 1372.

64 A se vedea, A.-S. BARthez, D. HoutciefF, Traité de droit civil (sous la direction de J. Ghestin), op.cit., p. 994, nr. 1372.

65 A se vedea, P. TAFFOREAU, op.cit., p. 226, nr. 446-1. 
contractul de bază. Ne vedem nevoiți să mai precizăm că, în peisajul format din garant, ordonator și beneficiar, se poate ivi un al patrulea actor: contragarantul. Relația de contra-garanție are loc între garant și contra-garant ${ }^{66}$. Contra-garanția îi beneficiază garantuluii ${ }^{67}$.

În măsura în care beneficiarul îi cere garantului-emitent plata sumei indicate în scrisoarea de garanție, cel din urmă are posibilitatea să refuze „,̂n caz de abuz sau de fraudă vădită” [art. 2321 alin. (3) C.civ.]. Casația franceză a decis că beneficiarul de la care emană certificate, aprobate de inginerul său şi care atestă o executare a contractului de bază în proporție de $100 \%$, nu putea ignora absența dreptului său și se face vinovat de abuz manifest ${ }^{68}$.

În clipa în care garantul execută scrisoarea de garanție, își plătește propria datorie, dar stinge, în tot sau în parte, datoria altuia (i.e., cea a ordonatorului ${ }^{69}$. Presupunând că suma pe care se angajează s-o plătească garantul este egală celei datorate în temeiul contractului de bază și că beneficiarul a fost plătit în totalitate de garantul-emitent, beneficiarul cu pricina nu mai poate reclama nimic de la ordonator ${ }^{70}$. Garantul care l-a plătit pe beneficiar se va îndrepta împotriva ordonatorului ${ }^{71}$ [art. 2321 alin. (4) C.civ.].

Nu este câtuși de puțin dificil să ne închipuim că sunt prezenți patru actori: 1) garantul, 2) beneficiarul, 3) ordonatorul și 4) contra-garantul. Garantul îl plătește pe beneficiar, dacă cel din urmă îl solicită. Apoi, garantul

${ }^{66}$ Ibid., p. 226, nr. 446-2.

${ }^{67}$ A se vedea, Ch. Albiges, M.-P. Dumont, op.cit., p. 221, nr. 255.

68 A se vedea, Com. 10 juin 1986, in G. Wiederkehr, X. Henry, A. Tisserand-Martin, G. VENANDET, P. ANCEL, P. GUIOMARD, op.cit., p. 2700.

${ }^{69}$ A se vedea, P. TAFFOREAU, op.cit., p. 243, nr. 500.

${ }^{70}$ Ibid.

${ }^{71}$ Ibid., p. 244, nr. 502. 
are un regres împotriva contra-garantului, care, desigur, îl va plăti pe garant ${ }^{72}$ (după cum am văzut, contra-garanția este o favoare a garantului). Contragarantul se va îndrepta, la urmă, împotriva ordonatorului ${ }^{73}$.

\section{Fideiusiunea - scurtă prezentare}

Fideiusiunea modernă este fructul unei evoluții seculare ${ }^{74}$. Ea este, potrivit unora, cea mai veche garanție, avându-și rădăcinile în Antichitate, astfel cum o demonstrează numeroase tăblițe găsite în Persia ${ }^{75}$.

În Roma, existau sponsio şi fidepromissio ${ }^{76}$. Ele presupuneau intervenția sau „adăugarea” unui promitent (i.e., ad promissores), fiind vorba despre un sponsor ori despre un fidepromissor ${ }^{77}$. Din câte se pare, sponsio și fidepromissio erau contracte verbis, încheiate prin schimbul de cuvinte sacramentale $^{78}$. Cele două contracte se deosebeau prin domeniul de aplicare rationae personae: sponsio era o convenție ce se putea forma doar între cetățeni romani, pe când fidepromissio era rezervată peregrinilor ${ }^{79}$. Obligațiile sponsorilor și ale fidepromisorilor nu treceau la urmașiso. În epoca

72 A se vedea, M. Mignot, op.cit., p. 233, nr. 597.

73 Ibid.

74 A.-S. Barthez, D. HoutciefF, Traité de droit civil (sous la direction de J. GHeSTIN), op.cit., p. 11, nr. 8 .

${ }^{75}$ A se vedea, J. Deslauriers, A. BENADIBA, Les sûretés au Québec, 2e édition, Wilson \& Lafleur, Montréal, 2018, p. 791, nr. 2351.

76 A se vedea, A.-S. Barthez, D. HoutciefF, Traité de droit civil (sous la direction de J. GHESTIN), op.cit., p. 14, nr. 12.

${ }^{77}$ Ibid.

78 Ibid.

79 Ibid.

${ }^{80}$ A se vedea, Vl. HANGA, Drept privat roman, Argonaut, Cluj-Napoca, 1996, p. 336.

\section{4}


clasică, insuficiența ce caracteriza sponsio și fidepromissio duce la nașterea fidejussio $^{81}$. Aceasta din urmă nu era ataşată persoanei şi se transmitea moștenitorilor ${ }^{82}$. Superioară din toate punctele de vedere față de sponsio și fidepromissio, fidejussio le-a dat lovitura de grație: Iustinian s-a preocupat numai de cea din urmă ${ }^{83}$.

Codul civil francez din $1804 \mathrm{i}$-a dedicat fideiusiunii art. 2011-2043, iar Codul civil român, din 1864, i-a închinat acestei garanții personale art. 1652168484. Actualmente, în România, fideiusiunea este situată la art. 2280-2320 C.civ. În Franța, ea este plasată la art. 2288-2320 C.civ.fr. ${ }^{85}$.

Common Law-ului american nu îi este străină fideiusiunea. Iată un exemplu pe care îl putem lectura în Restatement (Third) of Suretyship and Guaranty ${ }^{86}$ : pentru a-l convinge pe C să-i împrumute $\$ 10.000$ lui D, S este de acord să restituie împrumutul, în măsura în care D nu o face.

Contractul de fideiusiune este un acord între fideiusor şi creditor ${ }^{87}$; debitorul nu este parte în convenția aceasta ${ }^{88}$. Deși debitorul nu este contractant în contractul de fideiusiune, el rămâne un personaj cheie,

81 A se vedea, A.-S. Barthez, D. Houtcieff, Traité de droit civil (sous la direction de J. GHestin), op.cit., p. 17, nr. 15.

82 Ibid.

83 Ibid., p. 18, nr. 16.

${ }^{84}$ A se vedea, C. NACU, Comparațiune între Codul civil român şi Codul Napoleon, Editura Librăriei Leon Alcalay, București, p. 772-784.

85 A se vedea, G. Wiederkehr, X. Henry, A. Tisserand-Martin, G. Venandet, P. Ancel, P. GUIOMARD, op.cit., p. 2648-2699.

${ }^{86}$ A se vedea, The American Law Institute, Restatement of the Law Third. Restatement of the Law - Suretyship and Guaranty, American Law Institute Publishers, 1996, p. 7.

${ }^{87}$ A se vedea, Ph. Simler, op.cit., p. 16, nr. 11.

88 A se vedea, Com. 26 janv. 1988, în G. Wiederkehr, X. Henry, A. Tisserand-Martin, G. VenANDET, P. ANCEL, P. GuiOMARD, op.cit., p. 2652.

\section{5}


deoarece îl solicită pe fideiusor ${ }^{89}$. De cele mai multe ori, fideiusiunea se încheie cu acordul debitorului; datornicul principal trebuie să convingă un fideiusor să-l garanteze ${ }^{90}$; fideiusiunea, aşadar, se ivește la solicitarea debitorului, în sensul că acesta îl cheamă pe fideiusor să încheie contractul de fideiusiune cu creditorul ${ }^{91}$. Desigur, fideiusiunea poate fi perfectată fără știința debitorului sau chiar împotriva voinței sale (art. 2283 C.civ.). Oricum, ipoteza unei fideiusiuni încheiate făă ştiința datornicului principal şi, cu atât mai mult, situația uneia închegate contra voinței debitorului sunt aspecte cât se poate de teoretice ${ }^{92}$.

Referitor la contractul de fideiusiune, câteva probleme ne par interesante și demne să fie supuse discuției. Întâi, convenția de fideiusiune este accesorie sau subsidiară? Ar prinde bine să precizăm că accesoriul și subsidiarul nu trebuie confundate ${ }^{93}$. Accesoriu este angajamentul care există doar pentru a fi în serviciul principalului94 (i.e., pentru a servi un contract principal). Angajamentul subsidiar este cel care poate fi „pus în joc” doar în mod secundar, după ce se manifestă aspectul principa ${ }^{95}$. Unii autori cred că fideiusiunea nu este subsidiară, căci creditorul poate să-l urmărească întâi pe fideiusor sau să se îndrepte, în acelaşi timp, împotriva garantului şi a debitorului principal ${ }^{96}$. Desigur, atunci când beneficiul de discuțiune este

${ }^{89}$ A se vedea, D. LEGEAIs, op.cit., p. 61, nr. 56.

90 A se vedea, A. ТАMBA, Fideiusiunea în context: legăturile (i.e. relațiile) dintre debitor și fideiusor, Revista Română de Drept Privat nr. 4/2019, p. 368.

${ }^{91}$ A se vedea, A. TAMBA, op.cit., p. 368.

92 A se vedea, A.-S. BARthez, D. HoutciefF, Traité de droit civil (sous la direction de J. GHESTIN), op.cit., p. 36, nr. 33.

93 A se vedea, M. Cabrillac, Ch. Mouly, S. Cabrillac, Ph. Pétel, op.cit., p. 64, nr. 77.

94 Ibid.

95 Ibid.

96 Ibid. 
absent fie pentru că s-a renunțat expres la el [art. 2294 alin. (1) C.civ.], fie deoarece fideiusiunea este solidară între debitor și fideiusor ${ }^{97}$, pare imposibil de crezut că fideiusiunea ar fi subsidiară: fără discuțiune, fideiusorul nu-i poate cere creditorului să-l urmărească întâi pe debitor și doar după aceea pe garant. Mai departe, ne interogăm dacă fideiusiunea poate să fie oneroasă? Doi doctrinari pornesc de la ideea că criteriul onerozităţii se regăsește în relațiile dintre fideiusor şi debitor ${ }^{98}$; astfel, în clipa în care fideiusorul este remunerat de debitor, fideiusiunea are un caracter oneros ${ }^{99}$. După părerea noastră, o atare poziție are doza sa de straniu: de ce ne-ar interesa relația fideiusor-debitor pentru a stabili dacă legătura fideiusor-creditor (i.e., convenția de fideiusiune) este oneroasă? Dacă există o remunerație, ea este prezentă în raporturile dintre fideiusor şi debitor ${ }^{100}$ astfel că, eventual, aceste raporturi sunt oneroase, nu contractul de fideiusiune.

Atunci când fideiusiunea intră în scenă cu acordul debitorului, o suită de trei contracte o să ne atragă atenția. Contractul principal (e.g., un împrumut) se încheie între creditor şi debitor. Apoi, datornicul va îndupleca un fideiusor să-l garanteze. Astfel, o convenție se naşte între debitor şi fideiusor. Sigur, nu sunt uşor de analizat şi de stabilit raporturile care se construiesc între fideiusor şi debitor ${ }^{101}$. Dreptul roman îi acorda unui fidejussor actio mandati ${ }^{102}$. Deci, într-o concepție tradițională, debitorul îi dă

\footnotetext{
97 A se vedea, S. I. VIDU, Garanțiile executării obligațiilor, in L. PoP, I.-F. PoPA, S. I. VIDU, Drept civil. Obligațiile, ediția a II-a, revizuită și adăugită, Universul Juridic, București, 2020, p. 615 , nr. 545.

98 A se vedea, A.-S. BARThez, D. HoutciefF, Traité de droit civil (sous la direction de J. GHESTIN), op.cit., p. 91, nr. 110.

${ }^{99}$ Ibid., p. 91-92, nr. 110.

100 A se vedea, Ph. Simler, Ph. Delebecque, op.cit., p. 54, nr. 60.

101 A se vedea, D. LEGEAIS, op.cit., p. 61, nr. 56, nota de subsol nr. 29.

102 A se vedea, M. Cabrillac, Ch. Mouly, S. Cabrillac, Ph. PÉtel, op.cit., p. 48, nr. 54.
} 
mandat fideiusoruluii ${ }^{103}$; relația contractuală dintre cei doi ar fi un mandat. Totuși, este extrem de dificil să admitem că fideiusorul încheie fideiusiunea în numele și pe contul debitorului ${ }^{104}$; fideiusorul perfectează fideiusiunea în numele său personal ${ }^{105}$. În ochii noștri, stipulația de contract de fideiusiune este cea mai interesantă pistă ${ }^{106}$; raportul contractual fideiusor-debitor ar putea să fie denumit stipulație de fideiusiune pentru altul ${ }^{107}$. Într-adevăr, legătura fideiusor-debitor, ca stipulație de contract pentru altul, necesită ca fideiusorul să fie promitent, iar debitorul să joace rolul de stipulant ${ }^{108}$; creditorul ar fi terțul beneficiar; fideiusorul consimte la viitorul contract de aplicație (i.e., la fideiusiune); stipulaţia de contract dintre debitor şi fideiusor naște o opțiune contractuală în favoarea creditorului; în momentul în care creditorul își exercită opțiunea în sensul acceptării, contractul de aplicație (i.e., fideiusiunea) se formează între fideiusorul-promitent și creditor ${ }^{109}$. În sfârşit, cel de al treilea contract apare: fideiusiunea ${ }^{110}$ însăși, încheiată între fideiusor și creditor.

103 A se vedea, H. et L. Mazeaud, J. Mazeaud, Fr. Chabas, op.cit. (par Y. Picod), p. 24, nr. 8. 104 A se vedea, A.-S. Barthez, D. HoutciefF, Traité de droit civil (sous la direction de J. GHESTIN), op.cit., p. 38, nr. 35.

105 A se vedea, A. TAMBA, op.cit., p. 374.

106 Ibid., p. 383.

107 Ibid.

108 Ibid.

109 Ibid.

110 În România, fideiusiunea este contract solemn (art. 2282 C.civ.). Ținând cont de faptul că, în cadrul stipulației de contract (de fideiusiune) pentru altul, fideiusorul consimte la contractul de aplicație (i.e., la fideiusiune), stipulația de contract ar trebui să fie, la rândul său, solemnă. A se vedea, A. TAMBA, op.cit., p. 384. De asemenea, s-ar impune ca acceptarea opțiunii contractuale de către creditor să fie solemnă. A se vedea, A. TAMBA, op.cit., p. 384. În practică, însă, nu știm dacă toate acestea au loc ...

\section{8}


O consecință importantă a caracterului accesoriu al fideiusiunii este următoarea: fideiusorul poate invoca excepții sau apărări ce țin de datoria principală ori de contractul principal (e.g., prescripție extinctivă, plată, nulitate, novație, confuziune, compensație, rezoluțiune) ${ }^{111}$. Totodată, fiind accesorie, fideiusiunea se va „deplasa” alături de creanța principală dacă cea din urmă este transferată printr-o cesiune; desigur, cesiunea de creanță trebuie să-i fie făcută opozabilă fideiusorului (art. 1581 C.civ.).

În situația în care fideiusorul îl plătește pe creditor, cel dintâi are la îndemână două tipuri de regres împotriva debitorului ${ }^{112}$. Unul este regresul pe cale personală, iar celălalt este intitulat regres pe cale subrogatorie. Fideiusorului îi este cu putință ca, prin aceeași cerere, să acționeze pe ambele fronturi, astfel încât să cumuleze avantajele oferite de regresul personal și de cel subrogatoriu ${ }^{113}$.

\section{Scrisoarea de garanție v. fideiusiune. Cum le diferențiem?}

Scrisoarea de garanție este autonomă sau independentă. Așadar, garantul își va executa angajamentul fără să-i poată opune beneficiarului e.g., nulitatea contractului de bază, rezoluțiunea acestuia, neexecutarea sa ${ }^{114}$ ori o prescripție extinctivă referitoare la convenția de bază ${ }^{115}$. De asemenea, independența scrisorii de garanție are ca urmare faptul că, principial, ea nu se

\footnotetext{
${ }^{111}$ A se vedea, M. Cabrillac, Ch. Mouly, S. Cabrillac, Ph. PÉtel, op.cit., p. 57, nr. 66.

112 A se vedea, Y. PICOD, op.cit., p. 161, nr. 90.

113 Ibid.

114 A se vedea, Ph. SimLER, op.cit., p. 936, nr. 919.

115 A se vedea, P. TAFFOREAU, op.cit., p. 232, nr. 465.
}

\section{9}


transmite împreună cu creanţa garantată ${ }^{116}$. Fideiusiunea are un caracter accesoriu. Astfel, fideiusorului îi este cu putință să utilizeze apărări sau excepții ce sunt legate de datoria principală sau de contractul principal (e.g., prescripția extinctivă, nulitatea, rezoluțiunea) ${ }^{117}$. Totodată, fideiusiunea va însoți creanţa principală dacă aceasta din urmă este transferată printr-o cesiune de creanță.

Autonomia sau independența scrisorii de garanție este opusul caracterului accesoriu al fideiusiunii ${ }^{118}$. $\mathrm{Cu}$ toate acestea, contenciosul privitor la distincția dintre garanția autonomă și fideiusiune este clasic și abundent $^{119}$ (supra., nr. 1). Adesea, redactarea garanţiilor este confuză, contradictorie și neglijată ${ }^{120}$. În măsura în care actul este contradictoriu, jurisprudența franceză are tendința să califice pseudo-garanția autonomă drept o fideiusiune ${ }^{121}$ : una ca asta se întâmplă atunci când „corpul” actului face vorbire despre o garanție autonomă, dar mențiunea manuscrisă indică că garantul se angajează în calitate de fideiusor solidar ${ }^{122}$.

La urma urmei, diferențiem scrisoarea de garanție și fideiusiunea pe baza redactării documentului sau înscrisului; o redactare neglijată (i.e., căreia nu i se acordă suficientă atenție) ar putea determina instanțele să califice garanția personală într-o manieră la care părțile nu s-au așteptat.

116 Ibid., p. 232, nr. 466.

117 A se vedea, M. Cabrillac, Ch. Mouly, S. Cabrillac, Ph. PÉtel, op.cit., p. 57, nr. 66.

118 A se vedea, Ph. Simler, op.cit., p. 932, nr. 915.

119 A se vedea, A.-S. BARThEZ, D. HoutciefF, Traité de droit civil (sous la direction de J. GHestin), op.cit., p. 883, nr. 1235.

120 Ibid., p. 884, nr. 1235.

${ }^{121}$ A se vedea, M. Mignot, op.cit., p. 226, nr. 578.

122 Ibid. 
Sigur, într-un litigiu, este posibil ca oponenții să încerce să deosebească cele două garanții personale în acest fel: un adversar va susține că înscrisul este ad validitatem, ceea ce sugerează prezența fideiusiunii (art. 2282 C.civ.); celălalt va pretinde că înscrisul este doar ad probationem, ceea ce ar evoca o scrisoare de garanție. Ne îndoim că o asemenea dezbatere ar fi lămuritoare. După noi, „diavolul” distincției între scrisoarea de garanție și fideiusiune se află în redactare, nu în altceva. 